\title{
Memahami Kritik al-Qur’an terhadap Agama Lain ${ }^{1}$
}

\author{
Mun'im Sirry ${ }^{2}$
}

\begin{abstract}
This article discusses some Qur'anic verses which criticizes other religions, especially Jews and Christianity. The thesis of this article is that these criticisms reflect a conflict in the early Islam, and the formation of Muslim communal identity. At the end of the article, the writer discusses the most heated debate whether Islam abrogates previous religions.
\end{abstract}

\begin{abstract}
Abstrak
Artikel ini mendiskusikan beberapa ayat al-Qur'an yang mengkritik agama lain, terutama Yahudi dan Kristen. Tesis utama artikel ini adalah bahwa kritik-kritik tersebut merefleksikan suatu konflik di awal kemunculan Islam dan terbentuknya identitas komunal Muslim. Di bagian akhir tulisan, penulis mendiskusikan pertanyaan yang sangat hangat diperdebatkan apakah Islam menghapuskan agama-agama sebelumnya.
\end{abstract}

Keywords: tahrî̀, Yahūd, Hūd, Nașārā, millah

\section{Pendahuluan}

Banyak ayat al-Qur'an mengritik agama lain, terutama Yahudi dan Kristen. Kritik al-Qur'an mencakup soal-soal doktrinal dari keaslian kitab suci mereka (Q.2:75; 4:46; 513 dan 5:41) hingga ketuhanan Yesus dan Trinitas (Qs.5:72 dan 5:116), dan masalah sosial dari soal larangan mempercayai Yahudi dan Kristen (Qs.2:120) atau menjadikan mereka sebagai teman atau pemimpin

\footnotetext{
${ }^{1}$ Makalah ini disampaikan sebagai "Keynote Speech" the $3^{\text {rd }}$ QUHAS Annual Meeting, dengan tema "New Approaches to Islamic Texts," yang diselenggarakan pada tanggal 24 Desember 2014 di Auditorium Sekolah Pascasarjana UIN Jakarta.

${ }^{2}$ Assistant Professor di Department of Theology, University of Notre Dame dan the Kroc Institute for International Peace Studies, Notre Dame, Indiana, Amerika Serikat. E-mail: msirry@nd.edu
} 
(Qs.5:51) hingga seruan perang dan diskriminasi jizyah (Qs.9:29). Sementara kaum Muslim radikal menggunakan ayat-ayat itu untuk menjustifikasi tindakan kekerasan terhadap agama lain, sebagian orang Barat polemis merujuk kepada ayat-ayat serupa untuk memperlihatkan Islam sebagai agama tidak toleran. Hingga kini, ayat-ayat itu menjadi "favorit" kaum Muslim radikal dan Barat polemis, sementara kaum Muslim moderat dan inklusif menghindar mendiskusikannya dan justeru mem-"fovorit"-kan ayat-ayat lain yang tampak mendukung gagasan mereka.

Argumen yang hendak dikembangkan tulisan ini adalah: kritik-kritik alQur'an itu merefleksikan suatu konflik di awal kemunculan Islam dan terbentuknya identitas komunal Muslim. Pemicu kritik al-Qur'an adalah penolakan komunitas agama lain untuk mengakui kenabian Muhammad. Tulisan ini diawali dengan mendiskusikan konteks sektarian (meminjam istilah John Wansbrough: "sectarian milieu") saat Nabi Muhammad menyampaikan risalahnya. Dari diskusi ini diharapkan, pertama, kita bisa memahami kenapa muncul ayat-ayat kritik terhadap agama lain dan, kedua, kita punya dasar solid untuk menafsirkan ulang dalam konteks keragaman agama di zaman modern. Juga akan dijelaskan sejumlah problem yang telah menyulitkan para mufasir klasik dan modern. Di bagian akhir, kita akan diskusikan pertanyaan yang menyita perhatian banyak sarjana: apakah kehadiran Islam menghapuskan agama-agama sebelumnya.

\section{Al-Qur'an dan Konteks Sektarian}

Menurut literatur Muslim, sebagian ayat al-Qur'an turun di Mekah dan sebagian lain di Madinah. Kendati kedua bagian itu tidak sepenuhnya berlainan, ada perbedaan penting antara keduanya dalam beberapa hal. Di Mekah, misalnya, kritik-kritik al-Qur'an kerap diarahkan pada masyarakat pagan Arab, yang disebutnya mushrikūn. Kata ini diderivasi dari shirk yang bisa bermakna "politeisme" karena kaum politeis cenderung menyekutukan Tuhan dengan lainnya. Shirk juga berarti penyembahan berhala. Yang perlu digarisbawahi adalah tuduhan politeisme ataupun penyembahan berhala itu bersifat subyektif dan tak seorangpun menyebut agamanya sebagai bentuk penyembahan berhala ataupun politeisme. Baru-baru ini Patricia Crone, guru besar sejarah Islam awal pada Institute for Advaced Study di Princeton, menerbitkan studinya dan memperlihatkan bahwa orang-orang pagan Arab tidak kurang monoteis dibanding mereka yang percaya pada Tuhannya al-Qur'an. ${ }^{3}$ Seperti ditunjukkan

\footnotetext{
${ }^{3}$ Patricia Crone, "The Religion of the Qur'anic Pagans: God and the Lesser Deities," Arabica 57 (2010): 151-200.
} 
Gerald R. Hawting, sebenarnya al-Qur'an sendiri menggunakan kata "musyrikun" secara polemik yang ditujukan kepada orang-orang yang barangkali juga melihat diri mereka monoteis. ${ }^{4}$

Selama periode Mekah, tantangan utama yang dihadapi Nabi adalah bagaimana mengajak kaum musyrik Mekah meninggalkan penyembahan berhala menuju penyembahan Tuhan yang esa. Banyak ayat yang turun di Mekah merekam penolakan mereka atas ajakan Nabi (misalnya Qs.38:4-7). Sebagai respons, al-Qur'an menekankan dua argumen. Pertama, misi Nabi digambarkan sebagai kelanjutan dari risalah Nabi-nabi sebelumnya. Sejumlah ayat juga menyebut kitab-kitab terdahulu, seperti "suhuf Ibrahim dan Musa" (Qs.87:1819). Poinnya jelas untuk menegaskan, wahyu yang disampaikan Nabi sejalan dengan kandungan kitab-kitab sebelumnya. Kedua, implikasinya, mereka yang menolak seruan Nabi akan menghadapi hukuman serupa seperti dialami mereka yang menolak Nabi-nabi terdahulu. Maka, al-Qur'an menceritakan hukuman yang menimpa Fir'aun, misalnya, atau kaum 'Ad dan Tsamud. Sebuah studi menarik dilakukan oleh David Marshall mengungkapkan, bahwa narasi hukuman (punishment narratives) dalam al-Qur'an mengalami pergeseran dan perubahan dari periode ke periode berikutnya, dari yang bersifat temporal hingga eskatologikal. ${ }^{5}$

Karena Nabi lebih banyak bergelut dengan respons negatif kaum pagan Arab, tidaklah aneh jika kita tak menjumpai referensi langsung kepada kaum Yahudi dan Kristen. Dalam al-Qur'an, kaum Kristen disebut "Nașārā", sementara Yahudi kadang dipanggil "Yahūd", "Hūd", "al-ladhīna hādū" atau "Bani Isrā'ìl." Menarik dicatat, baik kata "Nașāarä" ataupun "Yahūd" hanya muncul di surat-surat Madinah, yang menunjukkan perhatian Nabi di Mekah tidak terkait mereka. Tak ada bukti historis bahwa komunitas Yahudi dan Kristen eksis di Mekah pada abad kelahiran Islam. Barangkali mereka tidak merasa nyaman hidup di tengah keberagamaan politeistik. Sungguhpun demikian, ada sejumlah ayat berbicara tentang Yahudi dan Kristen di Mekah secara positif, menyebut mereka dengan istilah "ahl al-kitāb." Seorang sarjana Inggris cukup berpengaruh, Richard Bell, memberikan kesaksian berikut: "Dalam keseluruhan periode Mekah, sikap Muhammad terhadap ahl al-kitāb -

\footnotetext{
${ }^{4}$ Lihat Gerald R. Hawting, The Idea of Idolatry and the Emergence of Islam (Cambridge: Cambridge University Press, 1999).

5 Lihat David Marshall, God, Muhammad and the Unbelievers (Richmond: Curzon Press, 1999).
} 
yang tentu saja meliputi kaum Yahudi dan Kristen - sangatlah bersahabat (consistently friendly)."

Sikap bersahabat Nabi ini terefleksi jelas dalam al-Qur'an. Mereka yang telah diberi kitab itu, kata al-Qur'an, "mengakuinya [al-Qur'an atau Muhammad] seperti halnya mereka mengakui anak-anak mereka" (Qs.620). "Manakala ia [Qur'an] dibacakan, mereka berkata 'kami mengimaninya. Ini kebenaran dari Tuhan kami”" (Qs.28:53). Al-Qur'an bahkan menggambarkan "mereka yang telah Kami berikan kitab itu bergembira atas apa yang telah diwahyukan kepadamu" (Qs.13:36). Para sarjana menawarkan beragam penjelasan tentang mengapa kaum Yahudi dan Kristen digambarkan seolah sumbringah dengan misi kenabian Muhammad. Menurut S.D. Goitein, Nabi memang mendapat respons positif dari Yahudi dan Kristen di Mekah. ${ }^{7}$ Pendapat ini juga dibenarkan Fazlur Rahman, kendati yang terakhir ini lebih hati-hati. Kata Rahman, "di antara pengikut Yahudi dan Kristen terdapat mereka yang mengafirmasi kebenaran misi Muhammad." ${ }^{\circ}$ Rahman mengakui betapa sulitnya menemukan bukti historis untuk mendukung klaim ini. Karena itu tidak tertutup kemungkinan, kata Rahman, deskripsi ayat-ayat Mekah terhadap ahl al-kitab semata didasarkan pada asumsi teoritis tentang bagaimana seharusnya Yahudi dan Kristen bersikap terhadap Muhammad dan Qur'an.

Saya lebih condong pada pendapat Rahman yang terakhir ini. Sepertinya Nabi memang punya ekspektasi tinggi bahwa kaum Yahudi dan Kristen akan menerima kenabiannya dan keotentikan wahyunya. Makanya beliau sangat kecewa ketika tiba di Madinah, awalnya bernama Yatsrib, ternyata mereka menolak ajakan Nabi. Sebagian ayat-ayat Madinah memperlihatkan sikap keras terhadap mereka. Agama Yahudi dan Kristenpun perlahan diperlakukan "lawan" dan muncul semacam "kompetisi" dengan ahl al-kitab. Sebagai contoh, Nabi Ibrahim, yang merupakan figur penting dalam sejarah Yahudi dan Kristen, kini diklaim peletak dasar agama Muhammad, bukan Yahudi dan Kristen. Hal seperti itu tidak terjadi sebelumnya. Pada periode Mekah, al-Qur'an lebih banyak memberikan perhatian pada Musa ketimbang Ibrahim. Bahkan kata "millah" (sering diartikan "komunitas keagamaan") tidak diasosiasikan secara eksklusif pada Ibrahim, melainkan "millatu Ibrāhìm wa Isḥāq wa Ya 'qūb"

6 Richard Bell, The Origin of Islam in Its Christian Environment (London: Macmillan, 1926), 147.

${ }^{7}$ Lihat S.D. Goitein, "The Concept of Mankind in Islam," dalam W. Warren Wagar (ed.) History and the Idea of Mankind (Albuquerque: University of New Mexico Press, 1971), 72-91.

8 Fazlur Rahman, Major Themes of the Qur'an (Minneapolis: Bibliotheca Islamica, 1982), 137. 
(Qs.12:38). Di Madinah, kata "millah" diposisikan sebagai agama Ibrahim dan menjadi cikal-bakal agama Muhammad. Al-Qur'an mulai menyalahkan mereka yang menganggap Ibrahim sebagai orang Yahudi atau Kristen (Qs.3:67), sebaliknya ia diberi julukan "haniff", sebuah istilah anigmatik."

Di sinilah kita lihat Ibrahim menjadi simbol kompetisi antara agama baru (Islam) dan agama-agama yang sudah mapan (Yahudi dan Kristen). Diskursus al-Qur'an tentang Ibrahim (Qs.2:124-141) berakhir dengan ayat-ayat berbicara tentang perubahan arah kiblat (Qs.2:142-150) dari Jerusalem menuju Mekah. Dan, perubahan itu sering digambarkan sebagai momen menentukan putusnya hubungan Nabi dengan Yahudi, dan masalah ini telah banyak didiskusikan. Sarjana Belanda C. Snouck Hurgronje mengajukan teori dikenal dengan "Muhammad's break with Jews." Pertanyaan yang menggelitik Hurgronje adalah: Apa motivasi Muhammad menjadikan Bapak Yahudi (Jewish patriarch) sebagai model Islam? Kesimpulan Hurgronje, Nabi menginginkan Islam terbebas dari bayang-bayang agama Yahudi. Ajakan al-Qur'an untuk kembali ke millah Ibrahim, menurut Hurgronje, ditujukan pada kaum Yahudi agar mereka meninggalkan inovasi yang dimunculkan belakangan dan kembali ke monoteisme murni yang diajarkan Ibrahim. ${ }^{10}$

Banyak sarjana menerima teori Hurgronje ini, tapi ada juga yang menolak. Rahman, misalnya, mempersoalkan teori "Muhammad's break with Jews," karena pandangan al-Qur'an tentang agama Ibrahim bukan inovasi Nabi setelah memutus hubungan dengan Yahudi. Rahman melihat perubahan narasi al-Qur'an tidak spontan. Bahkan di Mekah pun, katanya, agama Ibrahim diperkenalkan sebagai model monoteisme dan membedakannya dari keyakinan kaum pagan Mekah. Asumsi Rahman, Nabi sudah membentuk entitas agama tersendiri sejak di Mekah. Asumsi semacam ini belakangan dipersoalkan oleh sejarawan Islam awal seperti Fred Donner. Guru Besar di Universitas Chicago ini berpandangan, kristalisasi Islam sebagai sebuah identitas konfesional eksklusif terjadi lebih lambat daripada yang dipresentasikan tradisi Islam. ${ }^{11}$ Tanpa bermaksud terlibat lebih jauh dalam perdebatan di atas, kita bisa lihat alQur'an memang mengambil sikap sangat serius atas penolakan Yahudi terhadap

9 Untuk diskusi tentang kata "haniff" lihat Mun'im Sirry, "The Early Development of the Qur'anic Hanif," Journal of Semitic Studies 56 (2011): 345-366.

${ }^{10}$ Untuk diskusi tentang pandangan Hurgronje ini, lihat Willem A. Bijlefeld, "Controversies around the Qur'anic Ibrahim Narrative and Its 'Orientalist' Interpretations," The Muslim World 72 (1982).

${ }^{11}$ Lihat, Fred Donner, Muhammad and the Believers at the Origins of Islam (Cambridge, MA: Harvard University Press, 2010). Lihat juga Fred Donner, "From Believers to Muslims: Confessional Self-Identity in the Early Islamic Community," AlAbhath 50-51 (2002-2003): 9-53. 
misi kenabian Muhammad. Bahkan ketika berbicara tentang Yesus, sebagian ayat Madinah memuat polemik terhadap kaum Yahudi.

Telaahlah ayat-ayat yang menolak penyalipan Yesus (Qs.156-158). Para mufasir memahami ayat-ayat tersebut sebagai bukti Yesus tidak mati karena disalip, melainkan ada orang lain yang disalip sementara Yesus diangkat ke langit. Tapi, kalau dibaca cermat, ayat itu tidak secara langsung mengritik keyakinan Kristen, melainkan kritik terhadap Yahudi Madinah, karena yang ditolak adalah pengakuan kaum Yahudi bahwa penyalipan merupakan lambang kemenangan mereka. Tentu saja ada sejumlah ayat khusus mengritik keyakinan Kristen, yang merefleksikan interaksi Nabi dengan kaum Kristiani pada tahuntahun terakhir periode Madinah. Perlu segera ditambahkan, kita tidak seyogyanya memahami pemetaan kritik al-Qur'an di atas secara kronologis. Artinya, ayat-ayat Madinah awal sepenuhnya terkait Yahudi, dan Madinah akhir fokus pada Kristen. Terjadi tumpang-tindih dalam arti sebagian ayat yang mengritik Kristen juga muncul di awal periode Madinah. Namun demikian, secara umum, ayat-ayat Madinah akhir memosisikan Yesus dan Maryam di jantung kontroversi teologis. Dan dalam iklim polemik seperti itulah kritik alQur'an lahir. Dengan kata lain, kritik al-Qur'an perlu dipahami sebagai hasil dari sebuah proses formasi keagamaan yang kompleks.

\section{Ambiguitas Kritik al-Qur'an}

Kompleksitas formasi keagamaan awal juga terefleksi dalam ambiguitas kritik-kritik al-Qur'an. Penggunaan kata "ambiguitas" di sini merujuk pada kenyataan bahwa al-Qur'an tidak memiliki sikap tunggal dalam memperlakukan komunitas agama lain. Hal ini mudah dipahami karena banyak ayat al-Qur'an merespons fenomena beragam. Dan iklim sektarian al-Qur'an terekam dalam beragam topik kritik al-Qur'an itu. Namun demikian tidak berarti sikap alQur'an terhadap agama lain melulu bersifat kritik. Di tengah iklim sektarian itu, kita masih jumpai al-Qur'an memperlihatkan pandangan ekumenikal dengan melebarkan payung keselamatan hingga mencakup Yahudi, Kristen dan Sabean. Jika mengikuti kronologi Theodor Nöldeke, sarjana Jerman yang kesohor itu, ayat yang menjanjikan keselamatan bagi non-Muslim muncul di awal dan akhir periode Madinah (Qs.2:62 dan 5:69). Kenyataan inilah yang mendorong Mahmoud Ayoub untuk menyimpulkan, "baik kalimat maupun kandungan kedua ayat identik itu tidak bisa dikatakan telah diabrogasi." 12

${ }^{12}$ Mahmoud Ayoub, "The Qur'an and Religious Pluralism," dalam Roger Boase (ed.) Islam and Global Dialogue: Religious Pluralism and the Pursuit of Peace (Burlington, VT: Ashgate, 2005), 277. 
Pertanyaannya: Apa/siapa yang sebenarnya dikritik al-Qur'an? Pertanyaan ini sulit dijawab karena al-Qur'an tampak tidak mengarahkan kritikkritiknya kepada ajaran "mainstream" Yahudi dan Kristen. Dan, kenyataannya, sejumlah kritik al-Qur'an terhadap kaum Yahudi dan Kristen memang sulit dijelaskan. Mari kita diskusikan beberapa contoh. Misalnya, kritik al-Qur'an terhadap doktrin agama Kristen yang dianggap menyimpang, yakni Trinitas. Qs.4:171 mengajak kaum Kristiani percaya pada Tuhan dan Rasul-rasul-Nya, sembari menyerukan "Jangan katakan 'Tiga.' Hal itu lebih baik bagimu." Dalam Qs.5:73, dikatakan: "Telah kafir mereka yang mengatakan Allah itu ketiga dari tiga (atau, satu dari tiga)." Lalu, bagaimana dengan dua uqnum Trinitas yang lainnya? Dari Qs.5:116, banyak ulama berkesimpulan konsep Trinitas yang dipahami al-Qur'an terdiri dari Allah, Yesus, dan Maryam. Apakah al-Qur'an salah-paham terhadap doktrin Trinitas? Bukankah Trinitas Kristen adalah Bapak, Anak dan Roh Kudus?

Ada beberapa teori ditawarkan. Penjelasan standarnya dikemukakan oleh Geoffrey Parrinder, Guru Besar Universitas London, dalam bukunya Jesus in the Qur'an (1965). Kata Parrinder, al-Qur'an merespons praktik keagamaan sebuah sekte yang disebut Collyridians. Disebut demikian, karena sekte ini mempersembahkan roti kecil (dalam bahasa Yunani "collyrid") kepada Maryam. Sekte Collyridians ini, masih menurut Parrinder, eksis di Jazirah Arab pada abad keempat Masehi. Dia menyimpulkan, "Bisa jadi al-Qur'an merespons sekte menyimpang ini dan menolak penyembahan Maryam."13 Dua tahun setelah terbitnya buku Parrinder itu, W. Montgomery Watt menulis artikel pendek berjudul "Christianity Criticized in the Qur'an," dan mempertegas bahwa alQur'an sebenarnya tidak menyerang doktrin Kristen ortodoks, tapi bentukbentuk penyimpangan (Christian heresies). ${ }^{14}$ Problem dengan penjelasan Parrinder adalah kita tidak punya cukup informasi tentang eksistensi sekte Collyridians ini, dan pengaruhnya, jika ada, terhadap diskursus al-Qur'an masih diperdebatkan.

Ada penjelasan lain yang kerap diabaikan para sarjana. Yakni, kemungkinan al-Qur'an berdialog dengan teks-teks Kristen non-kanonikal yang mensejajarkan status Maryam dengan uqnum Trinitas, atau bahkan penjelmaan uqnum Trinitas itu sendiri. Gospel of Philip, misalnya, cenderung mengidentikkan Maryam dengan Roh Kudus, sementara Gospel of the Hebrew

${ }^{13}$ Geoffrey Parrinder, Jesus in the Qur'an (New York: Barnes \& Noble, 1965), 135.

14 Lihat W. Montgomery Watt, "Christianity Criticized in the Qur'an," The Muslim World 57 (1967): 197-201. 
mendeskripsikan Ibu Yesus itu sebagai inkarnasi malaikat Mikail. ${ }^{15}$ Walaupun penjelasan ini lebih masuk akal, kita masih dihadapkan pada pertanyaan sulit, kenapa al-Qur'an mengisyarakan pemahaman Trinitas sebagai tiga tuhan, padahal konsep Trinitas Kristen bukanlah politeisme melainkan monoteisme trinitarian?

Kita ambil contoh terkait Yahudi: mengapa al-Qur'an menuduh kaum Yahudi memanggil 'Uzair dengan sebutan "anak Tuhan”? Dalam Qs.9:30, disebutkan "Orang-orang Yahudi mengatakan 'Uzair anak Tuhan dan Kristen mengatakan Yesus anak Tuhan." Kesulitan pertama yang menghadang para mufasir adalah kenyataan bahwa kaum Yahudi tidak menyebut 'Uzair sebagai anak Tuhan, karena mereka tidak mengimani 'Uzair sebagaimana Kristen mengimani Yesus. Para mufasir sejak awal mengakui, kaum Yahudi tidak menyebut 'Uzair anak Tuhan; tapi mereka berbeda pendapat mengapa al-Qur' an membuat klaim tersebut. Mufasir awal seperti Tabari, Razi, Qurtubi hingga Ibn Katsir cenderung berpendapat, "Uzair punya kontribusi besar dalam merestorasi kitab suci Yahudi sehingga sebagian memberinya gelar "anak Tuhan." Penjelasan semacam ini dilatari keimanan bahwa al-Qur'an tidak mungkin mengandung informasi tidak akurat. Seperti didiskusikan Mahmoud Ayoub, para mufasir awal itu berusaha meminimalkan signifikansi gelar anak Tuhan bagi 'Uzair "dengan mengakui tidak semua orang Yahudi mengatakan demikian, tapi hanya segelintir orang bodoh di kalangan mereka."16 Lagi-lagi, kita sulit memastikan kenapa al-Qur'an melemparkan tuduhan kepada mereka secara umum.

Bahkan menyangkut isu yang banyak didiskusikan, seperti tuduhan tahrif (perubahan atau falsifikasi kitab suci Yahudi dan Kristen), kita sulit memastikan apa yang sebenarnya dikritik al-Qur'an. Secara umum, ulama terbelah ke dalam dua kubu: Sebagian mengatakan tahrif terjadi dalam teks kitab suci (tahrif al-nașs), sebagian lain berpendapat tahrif hanya menyangkut pemahaman dan penafsiran (tahrif al-ma'nā) sementara teks kitab suci mereka tetap otentik. Belakangan muncul tuduhan tahrif yang mencakup teks dan makna sekaligus. Problemnya, al-Qur'an tidak memberikan sikap tunggal.

${ }^{15}$ Untuk diskusi lebih lanjut, lihat Hans-Josef Klauck, Apocryphal Gospels: an Introduction (London: T\&T Clark, 2003); 38-42 dan 123-134; John Davidson, The Odes of Solomon: Mystical Songs from the Time of Jesus (Bath: Clear Press, 2005); lihat juga Chris Maunder, "Origins of the Cult of the Virgin Mary in the New Testament," in Chris Maunder (ed.) Origins of the Cult of the Virgin Mary (London: Burns and Oates, 2008), 23-39.

${ }^{16}$ Mahmoud Ayoub, "Uzayr in the Qur'an and Muslim Tradition," dalam William M. Brinner dan Stephen D. Ricks (eds.) Studies in Islamic and Judaic Traditions (Atlanta, GA: Scholar Press, 1986), 3-18. 
Artinya, ada ayat mengisyaratkan terjadinya distorsi tekstual, dan ayat lain distorsi pemaknaan. Sebelum kita lanjutkan diskusi betapa sulitnya menentukan kritik al-Qur'an menyangkut tahrif, kita bisa bertanya: Kenapa muncul tuduhan tahrif terhadap kitab suci pra-Qur'an? Pertanyaan ini perlu dijawab karena, seperti didiskusikan di atas, ayat-ayat Mekah cenderung mengafirmasi otentisitas dan orisinalitas kitab-kitab itu. Pertanyaan di atas bisa direformulasi begini: Kenapa terjadi pergeseran (shift) dalam pendekatan al-Qur'an terhadap kitab suci terdahulu?

Beberapa sarjana menjelaskan berikut: Tuduhan tahrif bisa dipahami sebagai bentuk kekecewaan Nabi terhadap orang-orang Yahudi. Awalnya Nabi bukan hanya berharap Yahudi dan Kristen akan mengakuinya, tapi juga meyakini isi kitab suci mereka sejalan dengan misi yang dibawanya. Itulah sebabnya beliau menyebut mereka "ahl al-kitab," orang-orang yang memiliki kitab suci. Namun ketika mereka menolak, tak ada cara bagi Nabi kecuali menuduh mereka telah menyembunyikan sifat-sifat kenabiannya dalam kitab suci mereka. Begitu pula ketika ternyata terdapat banyak perbedaan antara kitab suci mereka dan wahyu yang diterimanya, maka Nabipun menuduh ada yang salah dalam kitab suci terdahulu. Penjelasan semacam ini dapat ditemukan dalam karya sarjana-sarjana Barat yang awal hingga kontemporer, seperti Arent Jan Wensick, Frants Buhl dan Hava Lazarus-Yafeh. ${ }^{17}$ Kita boleh tidak setuju dengan teori munculnya klaim tahrif dalam al-Qur'an, tapi sebuah pertanyaan perlu dijawab: Jika al-Qur'an awalnya membenarkan kitab-kitab suci terdahulu, kenapa Yahudi dan Kristen yang membaca kitab-kitab itu tidak menerima kewahyuan al-Qur'an dan kemudian mengakui kenabian Muhammad?

Kritik al-Qur'an tidak berhenti pada soal tahriff. Dalam ayat-ayat lain alQur'an menuduh sebagian Yahudi dan Kristen sengaja menyembunyikan bagian tertentu dari kitab suci mereka (Qs.2:42, 140, 146, 159; 3:71, 187; 5:15 6:91). Kita juga jumpai al-Qur'an menuduh mereka melakukan pemalsuan: "Celaka bagi mereka yang menulis buku dengan tangannya, kemudian mengatakan 'Ini dari Tuhan,' sehingga mereka bisa perjual-belikan dengan harga murah" (Qs.2:79). Sebagian ahl al-kitab juga dituduh memelintir lidah mereka (Qs.3:78). Maka, kita bisa bertanya: Apa yang sesungguhnya dikritik al-Qur'an terkait kitab-kitab suci terdahulu? Sudah barang tentu kita akan temukan jawaban beragam dalam buku-buku tafsir. Terlepas kontribusinya yang besar

${ }^{17}$ Lihat Arent Jan Wensinck, Muhammad and the Jews of Medina, terj. Wolfgang Behn (Berlin: Klaus Schwarz Verlag, 1975); Frants Buhl, "Taḥinf," dalam M.Th. Houtsma, et al (eds.) The Encyclopaedia of Islam (Leiden: E.J. Brill, 1934); dan LazarusYafeh, "Tawrah," dalam Th. Bianquis, et al (eds.), The Encyclopaedia of Islam, New Edition (Leiden, Brill, 1998). 
dalam pengkayaan khazanah intelektual Islam, para mufasir acapkali gagal memecahkan teka-teki ambiguitas kritik al-Qur'an. Alih-alih, mereka menggunakan kritik-kritik tersebut sebagai bukti tekstual bahwa kehadiran alQur'an telah menghapuskan validitas kitab-kitab suci pra-Qur'an.

\section{Apakah al-Qur'an Supersesionis?}

Argumen penghapusan (atau supersesionisme, abrogasi) Islam atas agama-agama sebelumnya sebagian didasarkan pada asumsi bahwa kitab-kitab suci terdahulu sudah tidak valid lagi setelah diturunkannya al-Qur'an. Asumsi lain, Nabi datang untuk memurnikan religiositas dengan kembali ke model monoteisme Ibrahim. Pertanyaannya: Apakah kritik-kritik pedas al-Qur'an terhadap agama lain berarti menghapuskan keabsahan agama itu? Bagaimana alQur'an memosisikan diri vis-a-vis kitab suci terdahulu? Sebagai pengganti atau pengafirmasi?

Sudah menjadi pengetahuan umum, pertanyaan di atas seringkali dijawab secara dikhotomis: sebagian ulama menganggap al-Qur'an bersifat supersesionis dan sebagian lain melihat al-Qur'an tidak menghapuskan validitas kitab suci sebelumnya. Kedua kubu mengakui adanya ambiguitas sikap al-Qur'an, tapi berbeda cara merekonsiliasi posisi al-Qur'an yang tampak bertentangan itu. Di kalangan sarjana Muslim kontemporer, kedua pendekatan di atas diwakili oleh Tim Winter (nama Muslimnya: Abdul-Hakim Murad) dan Abdulaziz Sachedina. Guru Besar studi Islam di Universitas Cambridge, Winter berargumen "telaah jujur atas kitab suci kaum Muslim tampaknya mengorfirmasi pembacaan kalangan Sunni klasik yang mengarah pada supersesionisme Islam atas agamaagama sebelumnya." ${ }^{18}$ Di sisi lain, Sachedina yang Guru Besar di Universitas Virginia itu secara tegas mengatakan, "tidak ada ayat al-Qur'an yang secara eksplisit mendukung keyakinan Muslim belakangan bahwa al-Qur'an telah menghapuskan wahyu terdahulu." 19

Dari penelaahan terhadap iklim sektarian al-Qur'an di zaman Nabi, kita bisa tegaskan dikhotomi antara klaim supersesionis dan non-supersesionis itu terlalu simplistis dan tidak menggambarkan kompleksitas dinamika pertautan awal antara Islam dan agama-agama lain. Manakala persoalan hubungan Islam dan agama lain diformat dalam kerangka supersesionisme dan nonsupersesionisme, maka hanya tersedia dua opsi: menggenggam klaim

18 Tim Winter, "The Last Trump Card: Islam and the Supersession of Other Religions," Studies in Interreligious Dialogue 9 (1999), 137.

19 Abdulaziz Sachedina, "Political Implications of the Islamic Notion of 'Supersession' as Reflected in Islamic Jurisprudence," Islam and Christian-Muslim Relations 7 (1996), 162.

10 Vol. 3, No. 1, (2014) 
eksklusivisitas Islam atau menerima Yahudi dan Kristen sebagai agama sah. Problem argumen supersesionisme terletak pada anggapan bahwa kritik-kritik al-Qur'an terhadap agama lain sebagai "norma" dalam perbincangan antaragama. Padahal, seperti didiskusikan di atas, kritik-kritik al-Qur'an lahir dalam iklim polemik dan sektarian. Dalam suasana normal, demikian al-Qur'an mengajarkan, hubungan antar-agama diatur dengan prinsip-prinsip keseteraan, keadilan, dan saling menghormati.

Prinsip-prinsip ini berlaku baik dalam interaksi sosial maupun teologis. Pembacaan hati-hati terhadap kritik-kritik teologis al-Qur'an mengungkapkan, al-Qur'an tidak bermaksud mengganti agama-agama terdahulu, melainkan mengoreksi aspek-aspek yang dianggapnya menyimpang dari kemurnian. Ini sedikit menjelaskan kenapa al-Qur'an tampak tidak terlalu tertarik dengan diskursus teologis agama lain dan juga tidak menyajikan banyak informasi tentang agama lain, termasuk Yahudi dan Kristen. Seperti dicontohkan di atas, ketika menyinggung soal doktrin Trinitas yang cukup sentral dalam teologi Kristen, al-Qur'an hanya melarang mengatakan “tsalatsah" (Tiga, Trinitas?), dan tidak menjelaskan secara eksplisit apa yang dimaksud Trinitas. Hal ini menggiring sejumlah kalangan untuk menganggap al-Qur'an salah paham terhadap doktrin Trinitas. Barangkali bukan salah-paham, melainkan memang tidak tertarik dengan detailnya, dan hanya menyinggung sebagian pemahaman (yang tidak ortodoks) untuk dikoreksinya.

Dalam konteks ini, kita bisa melihat peran Muhammad sebagai Nabi pembaru (reformer) dan agama yang dibawanya juga mengemban semangat pembaruan, bukan pembatalan atau abrogasi. Nabi memisahkan diri dari jeratan politeisme pagan Arab dan mengadvokasi misi kembali ke monoteisme murni yang dicontohkan Ibrahim. Sebagai seorang pembaru, beliau hanya melihat bagian dari agama Yahudi dan Kristen untuk dikoreksi. F.E. Peters, profesor emiratus yang sangat produktif dari Universitas New York, melihat semangat reformasi Nabi Muhammad punya kesamaan dengan Nabi Isa. Dalam bukunya Jesus and Muhammad: Parallel Tracks, Parallel Lives, Peters menunjukkan banyak paralelisme dalam biografi Yesus dan Muhammad, termasuk perjuangan keduanya untuk mereformasi kultur keagamaan pada zamannya. Perbedaannya, kata Peters, reformasi Muhammad bersifat konservatif karena ingin mengembalikan kemurnian masa lalu (pristine past), sementara Yesus lebih progresif karena tidak memberangus akar tradisinya. ${ }^{20}$

${ }^{20}$ F.E. Peters, Jesus and Muhammad: Parallel Tracks, Parallel Lives (Oxford: Oxford University Press, 2011), 119. 
Perbedaan watak reformasi Yesus dan Muhammad seperti dijelaskan Peters ini terbuka diperdebatkan. Yang luput dari perhatian Peters adalah, baik Muhammad maupun Yesus tidak pernah mengklaim mengabrogasi agamaagama di zamannya. Yesus lahir sebagai seorang Yahudi hingga akhir hayatnya, sementara Muhammad mengaku mewarisi tradisi Ibrahim dan Nabi-nabi sebelumnya, termasuk Yesus. Jika demikian adanya, kenapa teologi supersesionisme begitu dominan dalam tradisi Kristen dan Islam? Menurut Sachedina, argumen supersesionisme Islam atas Kristen dan Yahudi bukan hanya menyerupai supersesionisme Kristen atas Yahudi tapi juga dipengaruhi perdebatan yang terjadi di kalangan kaum Kristiani. Kita kutipkan argumen Sachedina berikut: "Bukan mengada-ada jika kita katakan bahwa debat tentang Islam menghapuskan Kristen dan Yahudi, sungguhpun tidak didukung alQur'an, pasti masuk ke dalam pikiran kaum Muslim karena pengaruh perdebatan intens di kalangan umat Kristiani bahwa agama mereka telah menghapuskan Yahudi, terutama karena kaum Kristiani mengklaim pewaris sah dari kitab yang sama yang menjadi sumber hukum-hukum Yahudi. ${ }^{21}$

Tentu saja tidak mudah memastikan sejauhmana teologi supersesionis itu mempengaruhi pandangan kaum Muslim. Yang pasti, supersesionisme bisa dilacak jauh ke sejarah awal perkembangan gereja. Sejumlah sarjana berpendapat, teologi supersesionis itu bermula dari pandangan para penulis Perjanjian Baru dan diterima luas sejak zaman pasca-apostal hingga pertengahan abad kesembilanbelas. ${ }^{22}$ Namun demikian, dalam beberapa dekade terakhir dan mencapai kulminasi pada Konsili Vatikan kedua (1965), banyak upaya reinterpretasi dilakukan yang memungkinkan doktrin supersesionisme ini kian dianggap tidak relevan. Menyusul Nostra Aetate yang dikeluarkan Gereja Katolik itu, sejumlah gereja Protestan juga mengeluarkan deklarasi nonsupersesionis. Kita harus jujur akui, upaya reinterpresi ke arah teologi nonsupersesionis belum terlihat masif di kalangan umat Muslim sehingga cengkraman supersesionisme masih begitu kuat.

21 Abdulaziz Sacehdina, "Is Islamic Revelation an Abrogation of JudaeoChristian Revelation?: Islamic Self-identification in the Classical and Modern Age," Concilium 3 (1994), 32.

${ }^{22}$ Lihat, misalnya, R. Hann, "Supersessionism, Engraftment and Jewish-Christian Dialogue," Journal of Ecumenical Studies 27 (1990): 327-342; John S. Feiberg (ed.) Continuity and Discontinuity: Perspectives on the Relationship between the Old and New Testaments (Wheaton, IL: Crossway, 1988); Helga Croner (ed.) More Stepping Stones to Jewish-Christian Relations (New York: Paulist, 1985).

12 Vol. 3, No. 1, (2014) 


\section{Catatan Penutup}

Sebagai penutup, perlu ditegaskan di sini bahwa kritik-kritik keras terhadap agama lain itu tidak khas al-Qur'an. Dalam kitab suci agama lain juga ditemukan banyak diskursus yang bersifat menyerang komunitas agama lain. Dalam Injil Yohanes (8:31, 37, 44 dan 47): "Kemudian Yesus berkata kepada orang-orang Yahudi yang sudah percaya kepada-Nya, 'Kalau kalian hidup menurut ajaran-Ku kalian sungguh-sungguh pengikut-Ku"”; "Memang Aku tahu kalian ini keturunan Ibrahim. Namun kalian mau membunuh Aku, karena kalian tidak mau menerima pengajaran-Ku"; "Iblislah bapakmu, dan kalian mau menuruti kemauan bapakmu. Sedari permulaan Iblis itu pembunuh. Ia tidak pernah memihak kebenaran, sebab tidak ada kebenaran padanya. Kalau ia berdusta, itu wajar, karena sudah begitu sifatnya. Ia pendusta dan asal segala dusta"; "Orang yang berasal dari Allah, mendengar perkataan Allah. Tetapi kalian bukan dari Allah, itulah sebabnya kalian tidak mau mendengar."

Seperti kritik al-Qur'an, ayat-ayat polemik dalam Injil seyogyanya tidak dibaca secara terisolasi dari konteks sektarian dalam perkembangan awal gereja. Tulisan ini telah menunjukkan, kritik-kritik al-Qur'an muncul dalam iklim sektarian di mana Nabi dan para pengikutnya merintis terbentuknya identitas keagamaan terpisah dari Yahudi dan Kristen. Dan keunikan suatu identitas dibangun dengan menekankan perbedaan dari yang "lain," dan acapkali yang "lain" digambarkan secara negatif. Jelasnya, ayat-ayat kritik terkait konflik yang mengitari dinamika terbentuknya identitas keagamaan, dan karena itu perlu ditafsirkan ulang dalam konteks interaksi non-polemik pada zaman modern. Saya akhiri tulisan ini dengan mengutip sebuah observasi tajam dari Reuven Firestone, sarjana yang aktif dalam diskursus lintas-agama: "Tak bisa dimungkiri, polemik skriptural merekam ketegangan dan argumen peristiwa tertentu pada awal formasi keagamaan. Mengamalkannya sekarang jelas sebuah kesalahan dan kekeliruan dalam memahami peran dan signifikansi ayat-ayat polemik. $^{\text {23 }}$

\section{Daftar Pustaka}

Ayoub, Mahmoud. “The Qur'an and Religious Pluralism.” Dalam Roger Boase (ed.). Islam and Global Dialogue: Religious Pluralism and the Pursuit of Peace. Burlington, VT: Ashgate, 2005.

${ }^{23}$ Reuven Firestone, "The Way that New Religions Emerge," dalam Trialogue: Jews, Christians, and Muslims (New London, CT: Twenty-Third Publications, 2007), 53. 
-------. "Uzayr in the Qur'an and Muslim Tradition." Dalam William M. Brinner dan Stephen D. Ricks (eds.). Studies in Islamic and Judaic Traditions. Atlanta, GA: Scholar Press, 1986, 3-18.

Bell, Richard. The Origin of Islam in Its Christian Environment. London: Macmillan, 1926.

Bijlefeld, Willem A. "Controversies around the Qur'anic Ibrahim Narrative and Its 'Orientalist' Interpretations.” The Muslim World 72 (1982).

Buhl, Frants. "Tahrinf." Dalam M.Th. Houtsma, et al (eds.). The Encyclopaedia of Islam. Leiden: E.J. Brill, 1934.

Crone, Patricia. "The Religion of the Qur'anic Pagans: God and the Lesser Deities." Arabica 57 (2010): 151-200.

Croner, Helga (ed.). More Stepping Stones to Jewish-Christian Relations. New York: Paulist, 1985.

Davidson, John. The Odes of Solomon: Mystical Songs from the Time of Jesus. Bath: Clear Press, 2005.

Donner, Fred. "From Believers to Muslims: Confessional Self-Identity in the Early Islamic Community." Al-Abhath 50-51 (2002-2003): 9-53.

-------. Muhammad and the Believers at the Origins of Islam. Cambridge, MA: Harvard University Press, 2010.

Feiberg, John S. (ed.). Continuity and Discontinuity: Perspectives on the Relationship between the Old and New Testaments. Wheaton, IL: Crossway, 1988.

Firestone, Reuven. "The Way that New Religions Emerge." Dalam Trialogue: Jews, Christians, and Muslims. New London, CT: Twenty-Third Publications, 2007.

Goitein, S.D. "The Concept of Mankind in Islam.” Dalam W. Warren Wagar (ed.). History and the Idea of Mankind. Albuquerque: University of New Mexico Press, 1971, 72-91.

Hann, R. "Supersessionism, Engraftment and Jewish-Christian Dialogue." Journal of Ecumenical Studies 27 (1990): 327-342.

Hawting, Gerald R. The Idea of Idolatry and the Emergence of Islam. Cambridge: Cambridge University Press, 1999.

Klauck, Hans-Josef. Apocryphal Gospels: an Introduction. London: T\&T Clark, 2003.

Lazarus-Yafeh, Hava. "Tawrah." Dalam Th. Bianquis, et al (eds.). The Encyclopaedia of Islam, New Edition. Leiden, Brill, 1998.

Marshall, David. God, Muhammad and the Unbelievers. Richmond: Curzon Press, 1999. 
Maunder, Chris. "Origins of the Cult of the Virgin Mary in the New Testament." In Chris Maunder (ed.). Origins of the Cult of the Virgin Mary. London: Burns and Oates, 2008, 23-39.

Parrinder, Geoffrey. Jesus in the Qur'an. New York: Barnes \& Noble, 1965.

Peters, F.E. Jesus and Muhammad: Parallel Tracks, Parallel Lives. Oxford: Oxford University Press, 2011.

Rahman, Fazlur. Major Themes of the Qur'an. Minneapolis: Bibliotheca Islamica, 1982.

Sacehdina, Abdulaziz. "Is Islamic Revelation an Abrogation of Judaeo-Christian Revelation?: Islamic Self-identification in the Classical and Modern Age." Concilium 3 (1994).

------. "Political Implications of the Islamic Notion of 'Supersession' as Reflected in Islamic Jurisprudence." Islam and Christian-Muslim Relations 7 (1996).

Sirry, Mun'im. "The Early Development of the Qur'anic Hanif." Journal of Semitic Studies 56 (2011): 345-366.

Watt, W. Montgomery. "Christianity Criticized in the Qur'an." The Muslim World 57 (1967): 197-201.

Wensinck, Arent Jan. Muhammad and the Jews of Medina. Terj. Wolfgang Behn. Berlin: Klaus Schwarz Verlag, 1975.

Winter, Tim. "The Last Trump Card: Islam and the Supersession of Other Religions.” Studies in Interreligious Dialogue 9 (1999). 